\title{
Tissue and Plasma Somatomedin-C/Insulin-Like Growth Factor I Concentrations in the Human Fetus during the First Half of Gestation
}

\author{
A. JOSEPH D'ERCOLE, DAVID J. HILL, ALASTAIR J. STRAIN, AND LOUIS E. UNDERWOOD \\ Departments of Pediatrics, The University of North Carolina, Chapel Hill, NC 27514 and The University of \\ Sheffield, Children's Hospital, Sheffield, England
}

\begin{abstract}
To investigate the possible role of somatomedin-C/insulin-like growth factor I (Sm-C/IGF I) in early human development, we measured this peptide by radioimmunoassay in extracts of multiple tissues and in plasma from fetuses during the first half of gestation (9-19 wk). All tissues contained Sm-C/IGF I far in excess of that which could be accounted for by Sm-C/IGF I derived from blood entrapment. Lung and intestine had the highest concentrations $(166 \pm 35 \mathrm{mU} / \mathrm{g}, n=25$ and $160 \pm 20 \mathrm{mU} /$ $\mathrm{g}, \boldsymbol{n}=19$, respectively; mean \pm SEM) and liver the lowest $(67 \pm 16 \mathrm{mU} / \mathrm{g}, n=26)$. Plasma concentrations were 270 $\pm 20 \mathrm{mU} / \mathrm{ml}(n=20)$. Neither fetal weight $(6-258 \mathrm{~g})$ nor gestational age correlated with $\mathrm{Sm}-\mathrm{C} / \mathrm{IGF}$ I concentrations in any tissue or in plasma. These findings suggest that SmC/IGF I is synthesized in many human fetal tissues from as early as the 1st trimester. They also provide further evidence for an autocrine/paracrine role of this peptide growth factor. (Pediatr Res 20: 253-255, 1986)
\end{abstract}

\section{Abbreviations}

Sm-C, somatomedin-C

IGF, insulin-like growth factor

RIA, radioimmunoassay

Hgb, hemoglobin

The somatomedins, SM-C/IGF I and IGF II, are thought to stimulate fetal growth (1-3). Although cell surface receptors for these peptides are present from early in gestation (4-5), it is not known when the somatomedins are first synthesized in human gestation. Because multiple tissues make them, the somatomedins are thought to act in an autocrine or paracrine fashion, on their cells of origin or on nearby cells (6). To determine ontogeny and sites of synthesis, we measured Sm-C/IGF I concentrations in multiple tissues and plasma from human abortuses from 919 wk gestation. Our results suggest that Sm-C/IGF I is synthesized in multiple sites from as early as the 1 st trimester.

\section{MATERIALS AND METHODS}

Tissues. Tissues were obtained from 59 fetuses of prostaglandin-induced elective abortions performed at the Northern General Hospital, Sheffield, England. These fetuses were between 9

Received August 12, 1985; accepted November 5, 1985.

Correspondence A. Joseph D'Ercole, M.D., Department of Pediatrics, 509 Clinical Science Building 229H, University of North Carolina, Chapel Hill, NC 27514.

This work was supported by a USPHS Grant HD-08299, a March of Dimes National Birth Defect Foundation Basic Research Grant (1-758), the British Diabetic Association, the Yorkshire Cancer Research Campaign (Y.C.R.C.), and Birthright. A.J.D. is the recipient of a USPHS Research Career Development Award (HD 00435), and A.J.S. is supported by the Y.C.R.C. and $18 \mathrm{wk}$ gestational age, as calculated from the 1st day of the last menstrual period, and weighed between 6 and $258 \mathrm{~g}$. Although each study fetus was not the source of a complete set of tissues, there were no differences in the mean gestational ages or weights of donors for each tissue (Table 1). In the laboratory, tissues were dissected, rinsed in saline, blotted, and flash frozen in liquid nitrogen within $60 \mathrm{~min}$ of delivery. Intracardiac blood was collected (Table 1) into heparinized syringes, iced, and the plasma separated by centrifugation. All samples were stored at $-20^{\circ} \mathrm{C}$ until the time of extraction and assay (within 4 months). Procurement of human fetal tissues for this study was approved by the Ethics Committee of the Northern General Hospital, Sheffield and the Committee for the Protection of the Rights of Human Subjects, the University of North Carolina at Chapel Hill.

Tissue extraction and plasma treatment. Tissues were extracted for $\mathrm{Sm}-\mathrm{C} / \mathrm{IGF}$ I using a modification (6) of a procedure described previously (7). Tissues were pulverized under liquid nitrogen, extracted by incubation at $4^{\circ} \mathrm{C}$ for $2 \mathrm{~h}$ in $1 \mathrm{M}$ acetic acid (final $\mathrm{pH}=3.5-4.0$ ), and the supernatant was neutralized with $1 \mathrm{~N}$ $\mathrm{NaOH}$. Plasma was also incubated at $4^{\circ} \mathrm{C}$ for $2 \mathrm{~h}$, with an equal volume of $0.1 \mathrm{M}$ glycine-glycine $\mathrm{HCl}$ buffer (final $\mathrm{pH}=3.6$ ) before assay. To maximize the amount of immunoreactive Sm$\mathrm{C} / \mathrm{IGF}$ I that can be measured in plasma (8), separate aliquots of plasma were exposed to glycine-glycine $\mathrm{HCl}$ buffer at $37^{\circ} \mathrm{C}$ for $24 \mathrm{~h}$.

Estimation of tissue extractable $S m-C / I G F$ I derived from blood. Hgb was determined on extracts prior to neutralization by the method of Cosby and Furth (9), using a human $\mathrm{Hgb}$ standard (H 7379, Sigma Chemical Co., St. Louis, MO). The volume of serum that contaminated each extract was calculated as follows:

$$
\mathrm{ml} \text { serum } / \mathrm{ml} \text { extract }=\frac{[\mathrm{Hgb}] \mathrm{ex}}{[\mathrm{Hgb}] \mathrm{bl}} \times(1-\text { hematocrit })
$$

where $[\mathrm{Hgb}] \mathrm{ex}$ is the experimentally determined weight of $\mathrm{Hgb}$ (g) in $1 \mathrm{ml}$ of extract, [Hgb]bl is the concentration of $\mathrm{Hgb}$ in 1 $\mathrm{ml}$ of fetal blood, and hematocrit is expressed as a fraction. $\mathrm{Hgb}$ and hematocrit values used for calculations were: fetuses $<14$ wk gestation, $0.093 \mathrm{~g} / \mathrm{ml}$ and 0.73 , respectively, 14-17 wk, 0.107 $\mathrm{g} / \mathrm{ml}$ and $0.67,>17 \mathrm{wk}, 0.115 \mathrm{~g} / \mathrm{ml}$ and $0.64(10)$.

The contamination of tissue Sm-C/IGF I by Sm-C/IGF I in plasma was calculated by subtracting the mean plasma concentrations for the same age $( \pm 1 \mathrm{wk})$ fetuses from the total tissueextracted Sm-C/IGF I (7). The approximate contribution (mean \pm SEM) of plasma to the total Sm-C/IGF I extracted from tissues is as follows: $13 \pm 1.3 \%$ for liver, $6.9 \pm 0.5 \%$ for adrenal, $4.2 \pm$ $0.15 \%$ for muscle, $4 \pm 0.16$ kidney, $3.2 \pm 0.11 \%$ for skin, $2.9 \pm$ $0.14 \%$ for heart, and $<2 \%$ for pancreas, thymus, intestine, lung, and brain. With the exception of two liver extracts, there was no tissue in which plasma contamination accounted for more than $18 \%$ of the Sm-C/IGF I extracted.

$S m-C / I G F I R I A$. Sm-C/IGF I concentrations were estimated 
Table 1. Characteristics for each tissue studied

\begin{tabular}{|c|c|c|c|c|c|}
\hline \multirow[b]{2}{*}{ Tissue } & \multirow[b]{2}{*}{$n$} & \multicolumn{2}{|c|}{ Gestational age* (wk) } & \multicolumn{2}{|c|}{$\mathrm{Wt}^{*}(\mathrm{~g})$} \\
\hline & & Range & Mean \pm SEM & Range & Mean \pm SEM \\
\hline Adrenal & 19 & $9-18$ & $14.1 \pm 0.52$ & $6-239$ & $91.6 \pm 14.6$ \\
\hline Brain & 6 & $9-16$ & $13.3 \pm 0.97$ & $6-157$ & $12.0 \pm 21.0$ \\
\hline Heart & 20 & $11-18$ & $14.5 \pm 0.42$ & $8-239$ & $103.5 \pm 13.3$ \\
\hline Intestine & 19 & $9-18$ & $14.2 \pm 0.51$ & $6-239$ & $100.6 \pm 14.0$ \\
\hline Kidney & 24 & $9-18$ & $14.2 \pm 0.46$ & $6-239$ & $98.8 \pm 12.5$ \\
\hline Liver & 26 & $9-18$ & $14.2 \pm 0.44$ & $6-239$ & $103.4 \pm 12.5$ \\
\hline Lung & 25 & $9-18$ & $14.1 \pm 0.47$ & $6-239$ & $92.8 \pm 12.7$ \\
\hline Muscle & 22 & $12-18$ & $14.8 \pm 0.38$ & $10-239$ & $114.2 \pm 12.1$ \\
\hline Pancreas & 9 & $11-17$ & $14.7 \pm 0.60$ & $8-188$ & $107.6 \pm 17.6$ \\
\hline Plasma & 20 & $12-18$ & $15.4 \pm 0.43$ & $32-258$ & $111.5 \pm 16.2$ \\
\hline Skin & 17 & $12-18$ & $14.8 \pm 0.45$ & $10-239$ & $113.2 \pm 14.6$ \\
\hline Thymus & 5 & $11.5-18$ & $15.5 \pm 1.05$ & $23-239$ & $134.2 \pm 37.0$ \\
\hline
\end{tabular}

* There were no significant differences among fetal donors for any tissue.

in tissue extracts and plasma with a homologous RIA $(11,12)$ which employs a pool of adult human serum as standard. The RIA is highly specific for Sm-C/IGF I and has only $2 \%$ crossreactivity with IGF II (13). Concentrations are expressed as $\mathrm{mU} /$ $\mathrm{g}$ of wet weight for tissues and $\mathrm{mU} / \mathrm{ml}$ for plasma.

Validation of technique for measuring Sm-C/IGF I in extracts of human fetal tissues. Several experiments similar to those described previously for adult rat tissues $(6,7)$ were carried out to validate our methods for measurement Sm-C/IGF I in human fetal tissue extracts. Dose-response curves of extracts from each tissue were found to be parallel to those of the human serum standard. Known amounts of purified Sm-C/IGF I were added to extracts, and the added Sm-C/IGF I was shown to be quantified accurately in the RIA (the range of recovery of all tissues was $86-105 \%$ of the added Sm-C/IGF I), indicating that binding proteins were not reducing artificially the measurable peptide. To assure that the extraction procedure was freeing immunoreactive $\mathrm{Sm}-\mathrm{C} / \mathrm{IGF}$ I from binding proteins, and to exclude further any interference by binding proteins, representative extracts of eight tissues were subjected to Sephadex G 75 (Pharmacia) chromatography (bed volume $=65 \mathrm{ml}$ ) under acid conditions $(0.5 \mathrm{M}$ acetic acid, $\mathrm{pH}=3.6)$. The elution fractions corresponding to the free Sm-C/IGF I (Kav $=0.25-0.65)$ was collected, lyophilized, reconstituted, and subjected to RIA. These fractions contained between 63 and $95 \%$ of the Sm-C/IGF I measured in the acid extract prior to acid chromatography (76, $81,71,88,70,62,63$, and $95 \%$ for adrenal, heart, intestine, kidney, liver, lung, muscle, and skin, respectively), indicating that the extraction procedure was providing a reasonable estimate of the $\mathrm{Sm}-\mathrm{C} / \mathrm{IGF}$ I present.

\section{RESULTS}

Each of the eleven tissues studied contained Sm-C/IGF I (Fig. $1)$, and the mean tissue concentrations $(67-166 \mathrm{mU} / \mathrm{g})$ were at least seven times more than could be accounted by blood contamination. Concentrations were greatest in lung and intestine, and least in liver. When Sm-C/IGF I concentrations in tissues were correlated by linear regression analysis with body weight or gestational age of donors, no statistically significant associations were found.

The mean concentration $( \pm \mathrm{SEM})$ of $\mathrm{Sm}-\mathrm{C} / \mathrm{IGF} \mathrm{I}$ in fetal plasma that had been incubated for $2 \mathrm{~h}$ in acid was $200 \pm 20$ $\mathrm{mU} / \mathrm{ml}(n=20)$. Exposure to acid for $24 \mathrm{~h}$ resulted in a mean plasma concentration of $270 \pm 20 \mathrm{mU} / \mathrm{ml}(p=\mathrm{NS}$ by the Student's $t$ test). There was also no correlation between plasma Sm-C/IGF I concentration and fetal body weight.

\section{DISCUSSION}

This study shows that human fetal tissues from the first half of pregnancy contain immunoassayable Sm-C/IGF I far in excess of that which can be accounted for by contamination from fetal blood. Previous studies have reported that somatomedin peptides are released during in vitro culture of tissue explants from fetal mice (14), fibroblasts (15), myoblasts (16) and liver explants from fetal rats (17), and human fetal fibroblasts (18). We have found that human fetal connective tissues also release immunoassayable $\mathrm{Sm}-\mathrm{C} / \mathrm{IGF}$ I in vitro (19). These observations suggest that the $\mathrm{Sm}-\mathrm{C} / \mathrm{IGF}$ I detected in human tissues might be derived from in situ synthesis. If this is the case, Sm-C/IGF I may stimulate early human growth by autocrine or paracrine mechanisms.

In human fetal fluids $(20,21)$ and culture medium conditioned by human fetal tissues (19), the somatomedins are associated with binding proteins of approximately 40,000 molecular weight. Because these binding proteins may interfere with the measurement of somatomedin peptides (22), we extracted all tissues in acetic acid under conditions shown previously to separate Sm$\mathrm{C} / \mathrm{IGF}$ I from the binding proteins $(6,7)$. Our studies demonstrating complete recovery of purified Sm-C/IGF I added to the extracts, together with acid gel filtration studies show that there is no interference of binding proteins in the RIA, and that the differences among fetal tissue Sm-C/IGF I concentrations are not due to binding proteins. It also is unlikely that exposure to prostaglandins has altered the fetal serum Sm-C/IGF I concentrations, because results on samples collected in utero prior to

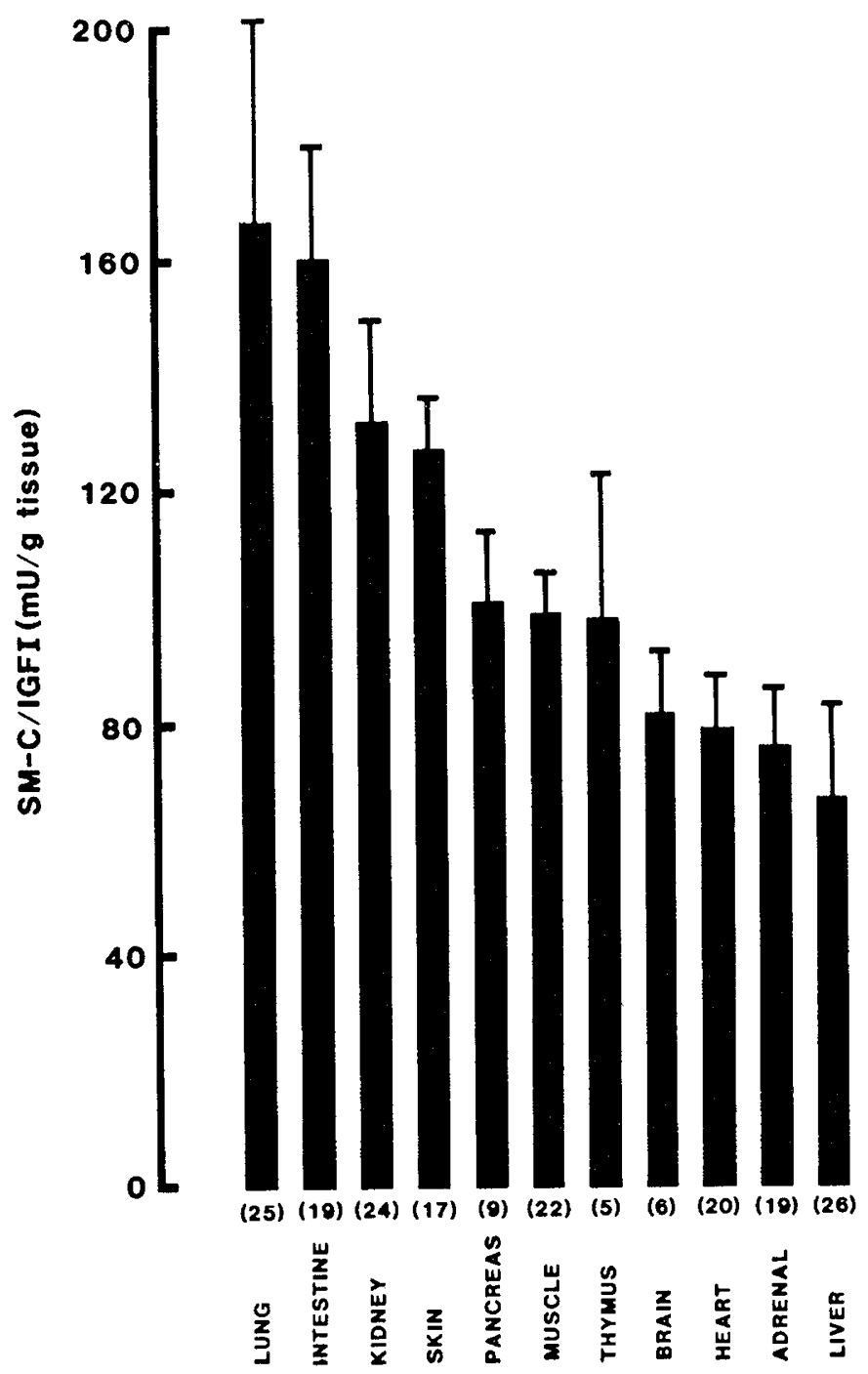

Fig. 1. Sm-C/IGF I concentrations (mean \pm SEM) in 11 human fetal tissues from 9-19 wk gestation. The number of samples, each from a separate fetus, are shown in parentheses. Brain tissue is predominantly cerebrum; intestine represents duodenum and jejunum; muscle (skeletal) is from the hamstring group, and skin is from the abdomen. 
prostaglandin-induced abortion (23) are similar to those reported herein.

The results in the present study, suggesting that many human fetal tissues have the capacity to produce Sm-C/IGF I, are similar to those reported previously for conditioned media of fetal mouse tissue explants (14). While the liver seems to be the major source of Sm-C/IGF I postnatally $(7,24)$, we believe that in the fetus, other tissues may be important for the production of this peptide. While the liver contributes approximately $5 \%$ to the weight of the mid-trimester fetus (25), another $3 \%$ can be accounted for by the lungs and $4-6 \%$ by skeletal muscle. Because both of the latter have two to three times more extractable Sm-C/IGF I/g tissue, their contribution to the Sm-C/IGF I in blood may be significant. The validity of this assumption depends on whether the peptide that can be extracted from a tissue reflects that which might be secreted. The lung appears to be a secretor of Sm-C/ IGF I, since this peptide has been identified in tracheal fluid of human newborns (26).

For a variety of reasons, including the observation that IGF II is higher in fetal than in adult rat serum (27), IGF II has been postulated to be the somatomedin most important for fetal growth (15). We know of no evidence that this is the case in man. Specifically, the IGF II content of mid- (23) and late (28) gestation human fetal plasma is low relative to adult values (29). Because Sm-C/IGF I is present in cord blood of human newborns and correlates positively with birth size and gestational age (1, $28,30)$, it might have a role in growth late in fetal life. However, little is known about the possible role of Sm-C/IGF I in early fetal growth. Human fetal brain and liver possess specific cell membrane receptors to $\mathrm{Sm}-\mathrm{C} / \mathrm{IGF}$ I from as early as $6 \mathrm{wk}$ gestation (5), and $\mathrm{Sm}-\mathrm{C} / \mathrm{IGF} \mathrm{I}$ increases the uptake of $\left[{ }^{3} \mathrm{H}\right]$ thymidine by fetal cartilage explants in vitro (31), suggesting that somatomedins may be anabolic early in fetal life.

This study does not provide direct evidence that Sm-C/IGF I stimulates early fetal growth. The presence of this peptide in tissues and blood, however, makes this a possibility. We found no evidence for change in Sm-C/IGF I content of any tissue or in plasma even though the fetuses studied varied in age, had a 40 -fold range of weights $(6-258 \mathrm{~g})$ and were experiencing brisk increases in the velocity of weight gain and linear growth (32). This suggests that Sm-C/IGF I is not the only factor that stimulates growth early in fetal life. Growth factors such as somatomedins, epidermal growth factor, and platelet-derived growth factor act synergistically to produce optimal rates of cell replication in vitro (33). Therefore, fetal growth in the presence of a constant stimulus of Sm-C/IGF I may be influenced by fluctuations in the concentrations of other peptide growth factors, changes in growth receptors, or changes in cellular responsivity.

Acknowledgments. The authors thank the staff of the Northern General Hospital for assistance with tissue collection, Dr. M. E. Svoboda and J. J. Van Wyk for providing purified Sm-C/IGF I, Mrs. Debra Bell and Mr. J. Milnes for technical expertise, Prof. R. D. G. Milner for critical discussion, and Ms. Kym Shlanta for preparing the manuscript.

\section{REFERENCES}

1. D'Ercole AJ, Underwood LE 1981 Growth factors in fetal growth and development. In: Novy MJ, Resko JA (eds) Fetal Endocrinology: ORPC Symposia on Reproductive Biology, Vol 1. Academic Press, Inc., New York, pp 155182

2. Underwood LE, D'Ercole AJ 1984 Insulin and somatomedins/insulin like growth factors in fetal and neonatal development. In: Daughaday WH (ed) Clinics in Endocrinology and Metabolism, Vol 13, Tissue Growth Factors. WB Saunders Co Ltd, East Sussex, England, pp 69-89

3. Milner RDG, Hill DJ 1984 Fetal growth control: the role of insulin and related peptides. Clin Endocrinol 21:415-433

4. Sara VR, Hall K, Misaki M, Fryklund L, Christensen N, Wetterberg L 1983 Ontogenesis of somatomedin and insulin receptors in the human fetus. $J$ Clin Invest 71:1084-1094

5. Grizzard JD, D'Ercole AJ, Wilkins JR, Moats-Staats BM, Williams RW 1984 Affinity labeled somatomedin-C receptors and binding proteins from the human fetus. J Clin Endocrinol Metab 58:535-543
6. D'Ercole AJ, Underwood LE 1985 Estimation of tissue concentrations of somatomedin-C/insulin like growth factor ( $\mathrm{Sm-C} / \mathrm{IGF} \mathrm{I})$. In: Barnes D, Sirbasku DA (eds). Methods Enzym (in press)

7. D'Ercole AJ, Stiles AD, Underwood LE 1984 Tissue concentrations of somatomedin-C: further evidence for multiple sites of synthesis and paracrine/ autocrine mechanisms of action. Proc Natl Acad Sci (USA) 81:935-939

8. Chatelain PG, Van Wyk JJ, Copeland KC, Blethen SL, Underwood LE 1983. Effect of in vitro action of serum proteases or exposure to acid on measurable immunoreactive somatomedin-C in serum. J Clin Endocrinol Metab $56: 376-383$

9. Crosby WH, Furth FW 1956 A modification of the benzidene method for measurement of hemoglobin in plasma and urine. Blood 11:380-383

10. Albritton EC (ed) 1952 Handbook of Biological Data. WB Saunders Co., Philadelphia, pp 41-46

11. Furlanetto RW, Underwood LE, Van Wyk JJ, D'Ercole AJ 1977 Estimation of somatomedin-C levels in normals and patients with pituitary disease by radioimmunoassay, $\mathbf{J}$ Clin Invest 60:648-687

12. Copeland KC, Underwood LE, Van Wyk JJ 1980 Induction of immunoreactive somatomedin-C in human serum by growth hormone: Dose response relationships and effect on chromatographic profiles. $J$ Clin Endocrinol Metab 50:690-697

13. Van Wyk JJ, Svoboda ME, Underwood LE 1980 Evidence from radioligand assays that somatomedin-C and insulin-like growth factor I are similar to each other and different from other somatomedins. J Clin Endocrinol Metab 50:206-208

14. D'Ercole AJ, Applewhite GT, Underwood LE 1980 Evidence that somatomedin is synthesized by multiple tissues in the feteus. Dev Biol 75:315-328

15. Adams SO, Nissley SP, Handwerger S, Rechler MM 1983 Developmental patterns of insulin-like growth factor I and II synthesis and regulation in rat fibroblasts. Nature 302:150-153

16. Hill DJ, Crace CJ, Nissley SP, Morrell D, Holder AT, Milner RDG 1985 Fetal rat myoblasts release both rat somatomedin-C/insulin-like growth factor I and multiplication stimulating activity in vitro. Partial characterization and biological activity of myoblast-derived Sm-C/IGF I. Endocrinology 117:2061-2072

17. Rechler MM, Eisen HJ, Higa OZ, Nissley SP, Moses AC, Schilling EE, Fennoy I, Bruni CB, Phillips LS, Baird KL 1979 Characterization of somatomedin (insulin-like growth factor) synthesized by fetal rat liver organ cultures. J Biol Chem 254:7942-7950

18. Atkison PR, Weidman ER, Bhaumick B, Bala RM 1980 Release of somatomedin-like activity by cultured WI-38 human fibroblasts. Endocrinology 106:2006-2012

19. Hill DJ, Crace CJ, Milner RDG 1985 Incorporation of $\left[{ }^{3} \mathrm{H}\right]$ thymidine by isolated human fetal myoblasts and fibroblasts in response to human placental lactogen (HPL): possible mediation of HPL action by release of immunoreactive somatomedin-C. J Cell Physiol 125:337-344

20. D'Ercole AJ, Drop SLS, Kortleve DJ 1985 Somatomedin-C/Insulin-like growth factor I (Sm-C/IGF I) binding proteins in human amniotic fluid and in fetal and postnatal blood: Evidence of immunologic homology. $J$ Clin Endocrinol Metab 61:612-617

21. Drop SLS, Kortleve DJ, Guyda HJ, Posner BI 1984 Immunoassay of a somatomedin-binding protein from human amniotic fluid: levels in fetal, neonatal, and adult sera. J Clin Endocrinol Metab 59:908-915

22. Daughaday WH, Mariz IK, Blethen SL 1980 Inhibition of access of bound somatomedin to membrane receptor and immunobinding sites: a comparison of radioreceptor and radioimmunoassay of somatomedin in native and acid-ethanol extracted serum. J Clin Endocrinol Metab 51:781-788

23. Ashton IK, Zapf J, Einschenk I, MacKenzie IZ 1985 Insulin-like growth factors (IGF) I and II in human foetal plasma and relationship to gestational age and foetal size during mid-pregnancy. Acta Endocrinol (in press)

24. Schwander JC, Hauri C, Zapf J, Froesch ER 1983 Synthesis and secretion of insulin-like growth factor and its binding protein by the perfused rat liver: Dependence on growth hormone status. Endocrinology 113:297-305

25. Gruenwald P, Ngoc Minh H 1960 Evaluation of body and organ weights in perinatal pathology. Am J Clin Pathol 34:247-253

26. Hill DJ, Watson R, Milner RDG 1984 Somatomedin activity in tracheal fluid from the newborn infant. J Clin Endocrinol Metab 59:231-234

27. Moses AC, Nissley SP, Short PA, Rechler MM, White RM, Knight AB, Higa OZ 1980 Elevated levels of multiplication-stimulating activity, an insulinlike growth factor, in fetal rat serum. Proc Natl Acad Sci USA 77:3649-3653

28. Bennett A, Wilson DM, Liu F, Nagashima R, Rosenfeld RG, Hintz RL 1983 Levels of insulin-like growth factors I and II in human cord blood. J Clin Endocrinol Metab 57:609-612

29. Zapf J, Walter H, Froesch ER 1981 Radioimmunological determination of insulin-like growth factors I and II in normal subjects and in patients with growth disorders and extrapancreatic tumor hypoglycemia. J Clin Invest 68:1321-1330

30. Gluckman PD, Johnson-Barrett JJ, Butler JH, Edgar BW, Gunn TR 1983 Studies of insulin-like growth factor I and II by specific radioligand assays in umbilical cord blood. Clin Endocrinol 19:405-413

31. Ashton IK and Spencer EM 1983 Effect of partially purified human somatomedin on human fetal and postnatal cartilage in vitro. Early Hum Dev 8:135-140

32. Southgate DAT 1978 Fetal measurements. In: Falkner F, Tanner JM (eds) Human Growth, Vol 1. Plenum Press, London, pp 379-395

33. Pledger WJ, Stiles CD, Antoniades HN, Scher CD 1978 An ordered sequence of events is required before BALB/3T3 cells become committed to DNA synthesis. Proc Natl Acad Sci (USA) 75:2834-2843 